Ethos: Jurnal Penelitian dan Pengabdian kepada Masyarakat, Vol 9, No.1, Januari 2021: 8-14

\title{
Penyusunan Artikel Ilmiah dan Pengenalan Open Journal System (OJS) BAgi GURU-GURU MATEMATIKA SMA Di KABUPATEN CiANJUR
}

\author{
${ }^{1}$ Ari Septian, ${ }^{2}$ Nia Jusniani, ${ }^{3}$ Muhammad Husni, ${ }^{4}$ Widyawati \\ ${ }^{1,2,3,4}$ Pendidikan Matematika, Universitas Suryakencana, Jawa Barat, Indonesia \\ email: 'ariseptian@unsur.ac.id, ${ }^{2}$ niajusniani56@gmail.com
}

\begin{abstract}
The purpose of community service activities is to provide insight and knowledge about the importance of scientific publications for teachers, introducing an open journal system (OJS) for scientific publications, teachers can create scientific articles published online and find out teachers' responses to the activities of article preparation scientific and introduction to the open journal system (OJS). The method used is the socialization, practice training in the use of the open journal system (OJS), mentoring by the team and evaluation. The participants of this activity are 50 mathematics teachers at the Cianjur. The evaluation instrument used teachers' response sheets to the activities of preparing scientific articles and the introduction of the open journal system (OJS). As a result of this activity, teachers gain insight and knowledge about the importance of scientific publications, $84 \%$ of mathematics teachers can apply the open journal system (OJS) for scientific publications, 78\% of mathematics teachers can make scientific articles published online and teachers' responses to the activities of preparing scientific articles and the introduction of the open journal system (OJS) by $88 \%$ or good category.
\end{abstract}

Keywords: Scientific Publications, Mathematics, Open Journal System

\begin{abstract}
Abstrak. Tujuan pada kegiatan pengabdian kepada masyarakat ini adalah untuk memberikan wawasan dan pengetahuan tentang pentingnya publikasi ilmiah bagi guru, memperkenalkan open journal system (OJS) untuk publikasi ilmiah, guru dapat membuat artikel ilmiah yang dipublikasikan secara online dan mengetahui respon guru-guru terhadap kegiatan penyusunan artikel ilmiah dan pengenalan open journal system (OJS). Metode yang digunakan yaitu dengan sosialisasi, latihan praktik penggunaan open journal system (OJS), pendampingan oleh tim dan evaluasi. Peserta kegiatan ini yaitu guru-guru matematika pada jenjang Sekolah Menengah Atas se-Kabupaten Cianjur sebanyak 50 orang. Instrumen evaluasi menggunakan lembar respon guru-guru terhadap kegiatan penyusunan artikel ilmiah dan pengenalan open journal system (OJS). Hasil kegiatan ini, guru mendapatkan wawasan dan pengetahuan tentang pentingnya publikasi ilmiah, $84 \%$ dari guru-guru matematika dapat mengaplikasikan open journal system (OJS) untuk publikasi ilmiah, $78 \%$ dari guru-guru matematika dapat membuat artikel ilmiah yang dipublikasikan secara online dan respon guru-guru terhadap kegiatan penyusunan artikel ilmiah dan pengenalan open journal system (OJS) sebesar $88 \%$ atau kategori baik.
\end{abstract}

Kata Kunci: Publikasi Ilmiah, Matematika, Open Journal System

\section{Pendahuluan}

Guru pada zaman sekarang ini dituntut profesional, handal, dan kompeten (Maskur et al., 2020). Hal ini sudah menjadi tuntutan masyarakat modern, maka wajar dan pantas bahwa sekarang ini menulis dalam bentuk publikasi ilmiah adalah sarana untuk meningkatkan kemampuan guru dalam pengembangan profesi mereka lebih maju (Praharani, 2007).

Publikasi ilmiah dapat dimaknai sebagai upaya untuk menyebarluaskan suatu karya pemikiran atau gagasan seseorang atau sekelompok orang dalam 
bentuk ulasan ilmiah dan laporan penelitian baik yang sederhana seperti Penelitian Tindakan Kelas dan juga penelitian yang lebih kompleks, makalah, buku atau artikel (Ceha, Prasetyaningsih, Bachtiar, \& Nana S., 2016). Publikasi ilmiah yang dilakukan guru pada dasarnya merupakan wujud dari profesionalisme guru (Rathert \& Okan, 2015).

Karya Tulis Ilmiah adalah Karya Ilmiah (Scientific Paper) dalam bentuk tulisan cetak atau non cetak (dengan memenuhi kaidah dan etika keilmuan yang dikukuhkan dan ditaati oleh masyarakat keilmuan), yang disusun secara perorangan atau kelompok mengenai penelitian/pengkajian suatu pokok bahasan atau pengembangan gagasan tertentu, dengan cara melakukan identifikasi, deskripsi, analisis, dan memberikan konklusi ataupun rekomendasi (Asropi, 2014). Karya Tulis Ilmiah merupakan karya tulis yang menyajikan gagasan, deskripsi atau pemecahan masalah secara sistematis, disajikan secara objektif dan jujur, dengan menggunakan bahasa baku, serta didukung oleh fakta, teori, dan atau bukti-bukti empirik. (Wardani, dkk, 2007). Suharjono (2006) menyatakan bahwa karys tulis ilmiah dapat diartikan sebagai laporan tertulis tentang (hasil) suatu kegiatan ilmiah.

Karya Tulis Ilmiah juga didefinisikan sebagai karya pemikiran yang ditulis atas hasil penelitian/kajian dan didukung dengan sajian fakta/data/bukti empiris dan ditulis dengan mengikuti kaidah penulisan ilmiah. Karya, merupakan hasil dari gagasan dan upaya sendiri baik bersifat penemuan maupun perumusan yang baru dari hal yang sudah ada, dan bukan merupakan gagasan atau upaya orang lain. Tulis, bahwa gagasan dan upaya tersebut diwujudkan dalam bentuk bahasa tulisan. Ilmiah, bahwa gagasan dan upaya tersebut merupakan hasil dan kegiatan yang didasarkan teori dan/atau fakta serta dianalisis dengan cara yang dapat dipertanggungjawabkan.

Karya tulis ilmiah merupakan gabungan narasi, deskripsi, dan eksposisi yang penulisannya didasarkan pada suatu penalaran atau logika tertentu, didukung bukti, dan disertai dengan argumen. Penalaran atau logika berhubungan dengan keabsahan penarikan kesimpulan, sedangkan argumen berhubungan dengan kebenaran premis yang digunakan sebagai dasar penarikan kesimpulan. Tulisan argumentasi bertujuan untuk mengubah sikap dan pendapat orang lain dengan menggunakan prinsip-prinsip logika sebagai alat bantu utama. Beberapa hal penting yang harus diperhatikan oleh penulis dalam membuat karya tulis ilmiah: (1) mendasarkan pada fakta/informasi, bukti, dan konstelasi faktual/informasi; (2) mempertimbangkan pandanganpandangan atau pendapat-pendapat yang bertentangan; (3) mengemukakan pokok persoalan dengan jelas; (4) menyelidiki persyaratan-persyaratan yang masih diperlukan; (5) mengandung kebenaran; (6) menghindari penggunaan istilah yang dapat menimbulkan prasangka; (7) memberikan batasan pada istilah yang dapat menimbulkan ketidaksepakatan.

Seiring dengan dikukuhkannya guru sebagai jabatan fungsional. Jika dikaji lebih dalam, Isi Keputusan Menteri ini sebenarnya telah memberikan pesan tidak langsung kepada kita bahwa pada dasarnya guru adalah seorang ilmuwan. Hal ini sejalan dengan pemikiran Hamalik (2011) bahwa salah satu peran guru adalah sebagai ilmuwan, yang berkewajiban tidak hanya menyampaikan pengetahuan yang dimiliki kepada muridnya, akan tetapi juga berkewajiban mengembangkan pengetahuan itu dan terus menerus memupuk pengetahuan yang dimilikinya. Dengan kata lain, guru 
berkewajiban untuk membangun tradisi dan budaya ilmiah (Inayah, Septian, \& Suwarman, 2020).

Kegiatan publikasi ilmiah guru semakin diperkuat dengan hadirnya Permenpan dan RB No. 16 tentang Jabatan Fungsional Guru dan Angka Kreditnya. Semula kewajiban publikasi ilmiah hanya dikenakan kepada guru yang akan naik pangkat dari Golongan IV.a ke atas. Namun berdasarkan Permenpan dan RB ini, kegiatan publikasi ilmiah guru harus dilakukan oleh guru yang akan naik ke golongan III.c.

\section{Perguruan Tinggi sebagai salah} satu pencetak calon guru bertanggungjawab dalam memberikan wawasan dan pengetahuan tentang publikasi ilmiah (N, Listihana, \& Nofrizal, 2018). Oleh karena itu, sebagai upaya meningkatkan kemampuan guru dalam mempublikasikan artikel ilmiah hasil penelitiannya maka Program Studi Pendidikan Matematika Universitas Suryakancana memberikan pelatihan penyusunan artikel ilmiah dan pengenalan Open Journal System.

Dari latar belakang di atas, terungkap bahwa pentingnya penulisan artikel ilmiah dan publikasinya menjadi persoalan utama dalam rangka menciptakan Guru-Peneliti. Guru tidak hanya mengajar di kelas, namun harus menjadi peneliti dalam mengidentifikasi masalah pembelajaran di kelas dan solusinya. Permasalahan yang dihadapi guru tidak hanya sebatas memahami materi dan mengajarkannya di kelas, tetapi, pendekatan, model dan metode mengajar, serta pengembahan bahan ajar dirasa perlu ditingkatkan kualitasnya.

Tujuan dalam pengabdian masyarakat ini yaitu untuk memberikan wawasan dan pengetahuan tentang pentingnya publikasi ilmiah bagi guru, memperkenalkan open journal system (OJS) untuk publikasi ilmiah, guru dapat membuat artikel ilmiah yang dipublikasikan secara online dan mengetahui respon guru-guru terhadap kegiatan penyusunan artikel ilmiah dan pengenalan open journal system (OJS).

Kegiatan ini melibatkan instansi MGMP Matematika SMA Kabupaten Cianjur dan Program Studi Pendidikan Matematika FKIP Universitas Suryakancana. Bagi guru yang tergabung dalam MGMP Matematika SMA Kabupaten Cianjur, kegiatan ini bermanfaat untuk meningkatkan kualitas Guru matematika sehingga diharapakan memberikan kontribusi dalam meningkatkan kualitas sekolah. Bagi Program Studi Pendidikan Matematika FKIP Universitas Suryakancana, kegiatan ini merupakan bentuk pengabdian masyarakat yang merupakan salah satu misi dari Tri Dharma Perguruan Tinggi.

\section{Metode}

Metode yang digunakan dalam kegiatan pengabdian kepada masyarakat ini yaitu sosialisasi, latihan praktek, pendampingan, dan evaluasi kegiatan.

Pada tahapan sosialisasi, pemateri memberikan matemati tentang kebijakan publikasi ilmiah yang berkenaan dengan guru, permasalahan kenaikan jabatan/golongan, dan kegiatan kredit poin yang harus dicapai para guru.

Pada tahap kedua yaitu latihan praktek, pelatihan tentang pengenalan open journal system (OJS) sebagai sarana publikasi ilmiah. Pada sesi ini dijelaskan bagaimana guru dapat menggunakan open journal system dalam mengakses secara online artikelartikel yang berkaitan dengan bahan penelitian ataupun referensi.

Tahap berikutnya yaitu pendampingan. Kegiatan pendampingan ini melibatkan dosen dalam mendampingi guru membuat artikel ilmiah yang berstandar nasional. Pada kegiatan pendampingan ini 5 guru didampingi oleh 1 dosen. 
Tahap terakhir yaitu evaluasi kegiatan. Pada tahap ini, guru mengisi angket tentang kegiatan penyusunan artikel ilmiah dan pengenalan open journal system (OJS).

Kegiatan ini dilaksanakan di SMAN 1 Cianjur pada hari rabu dan kamis tanggal 14-15 Maret 2018. Peserta dalam kegiatan ini adalah para guru matematika SMA di Kabupaten Cianjur. Tim Pemateri dari dosen Program Studi Pendidikan Matematika Universitas Suryakancana dan Guru yang tergabung dalam pengurus MGMP Matematika SMA di Kabupaten Cianjur.

Instrumen yang digunakan dalam pengabdian kepada masyarakat ini yaitu lembar penilaian untuk guru dalam mengaplikasikan open journal system (OJS), lembar penilaian untuk guru dalam membuat artikel ilmiah yang berstandar nasional, dan kuesioner/angket dalam kegiatan penyelenggaran kegiatan penyusunan artikel ilmiah dan pengenalan open journal system (OJS).

Teknik analisis data yang digunakan yaitu menghitung persentase dari setiap jawaban di lembar penilaian ataupun kuesioner.

\section{Hasil dan Pembahasan}

Pelaksanaan kegiatan pengabdian masyarakat dengan nama kegiatan "Penyusunan Artikel Ilmiah dan Pengenalan Open Journal System (OJS) bagi Guru-Guru Matematika SMA di Kabupaten Cianjur" ini dilaksanakan pada hari rabu dan kamis, tanggal 14-15 Maret 2018 di SMAN 1 Cianjur.

Kegiatan ini melibatkan instansi MGMP Matematika SMA Kabupaten Cianjur dan Program Studi Pendidikan Matematika FKIP Universitas Suryakancana. Bagi guru yang tergabung dalam MGMP Matematika SMA Kabupaten Cianjur, kegiatan ini bermanfaat untuk meningkatkan kualitas Guru matematika sehingga diharapakan memberikan kontribusi dalam meningkatkan kualitas sekolah. Bagi Program Studi Pendidikan Matematika FKIP Universitas Suryakancana, kegiatan ini merupakan bentuk pengabdian masyarakat yang merupakan salah satu misi dari Tri Dharma Perguruan Tinggi.

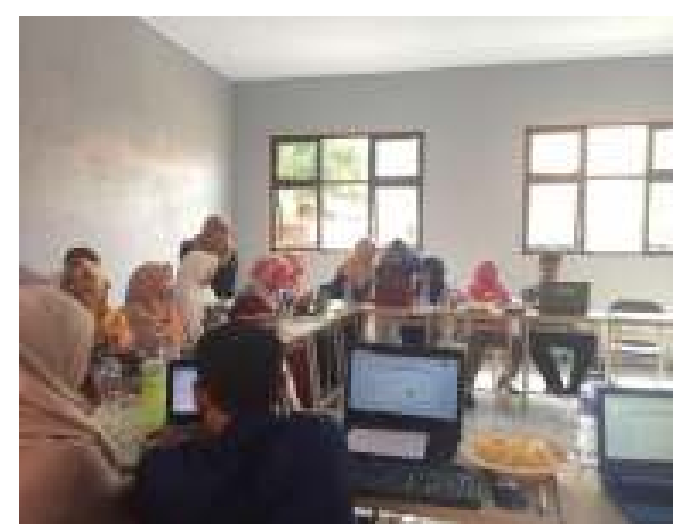

Gambar 1. Kegiatan Sosialisasi Penyusunan Artikel Ilmiah

Pada Gambar 1 memperlihatkan kegiatan yang dilakukan yaitu sosialisasi penyusunan artikel ilmiah bagi guru matematika SMA. Ada beberapa hal yang dilakukan dalam kegiatan ini. Pertama, dasar hukum kewajiban penyusunan artikel ilmiah bagi guru. Kedua, menjelaskan bagaimana mempublikasikan artikel ilmiah pada Open Journal System. Pada sesi pertama, dijelaskan dasar hukum diwajibkannya guru membuat artikel ilmiah. Guru diharapkan dapat meningkatkan profesionalismenya dan dapat membawa perubahan dalam pembelajaran matematika. 


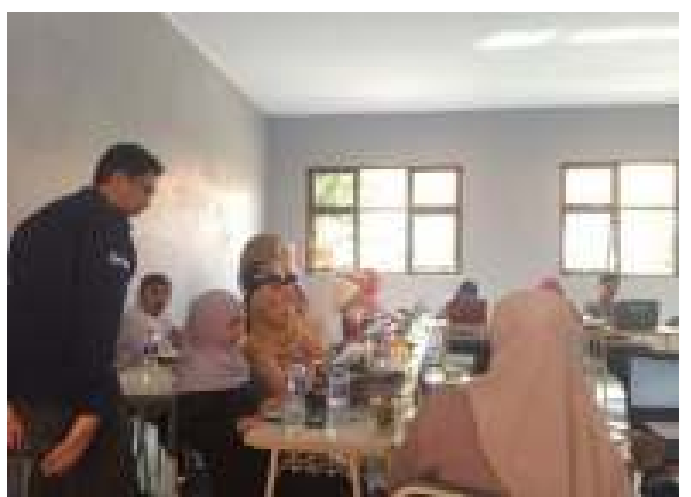

Gambar 2. Kegiatan Mengaplikasikan Open Journal System (OJS)

Pada Gambar 2 memperlihatkan guru-guru matematika menggunakan Open Journal System dalam publikasi ilmiah. Pada sesi ini, menjelaskan cara menggunakan Open Journal System. Penjelasan ini penting, supaya guru mengetahui bahwa artikel ilmiah dapat dipublikasikan secara nasional dan bersifat online.

Penilaian tentang memperkenalkan open journal system (OJS) untuk publikasi ilmiah untuk guruguru matematika disajikan pada Tabel 1.

Tabel 1. Penilaian tentang memperkenalkan open journal system

(OJS) untuk publikasi ilmiah

\begin{tabular}{lc}
\multicolumn{1}{c}{ Indikator } & Persentase \\
\hline $\begin{array}{l}\text { Penguasaan } \\
\text { Teknologi }\end{array}$ & $86 \%$ \\
\hline $\begin{array}{l}\text { Pengetahuan tentang } \\
\text { OJS }\end{array}$ & $82 \%$ \\
\hline Praktek & $84 \%$ \\
\hline \multicolumn{1}{c}{ Rata-rata } & $\mathbf{8 4} \%$ \\
\hline
\end{tabular}

Berdasarkan Tabel 1, Penilaian tentang memperkenalkan open journal system (OJS) untuk publikasi ilmiah untuk guru-guru matematika sudah baik. Diperoleh persentase sebesar rata-rata 84 $\%$ atau termasuk kategori baik. Kegiatan pada sesi ini berlangsung dengan sangat baik, guru-guru termotivasi dalam menggunakan open journal system (OJS) karena mereka baru menggunakan publikasi secara online yang belum pernah mereka dapatkan. Guru memahami dari bagaimana masuk ke open journal system (OJS) yang dicontohkan dengan tampilan dari PRISMA atau jurnal pendidikan matematika. Setelah itu, para guru melakukan pencarian arsip artikel yang sudah terbit sehingga memahami bahwa jurnal itu tidak hanya cetak, namun dapat juga secara online. Beberapa fitur di PRISMA juga dikenalkan, dari mulai bagaimana membuat akun dan password, mengirim naskah, dan sebagainya. Hal ini sejalan dengan penelitian sebelumnya bahwa beberapa fitur di open journal system (OJS) dapat mudah digunakan oleh setiap orang (Willinsky, 2005).

Sesi ketiga, guru simulasi/latihan praktek dalam membuat artikel ilmiah dari penelitian yang sudah ada sebelumnya. Pada sesi ini juga, guru diberi kesempatan untuk mempresentasikan artikel ilmiah yang dibuat.

Penilaian tentang guru-guru matematika dalam membuat artikel ilmiah yang dipublikasikan secara online disajikan pada Tabel 2.

Tabel 2. Penilaian tentang guru-guru matematika dalam membuat artikel ilmiah yang dipublikasikan secara

\begin{tabular}{lc}
\multicolumn{2}{c}{ online } \\
\hline \multicolumn{1}{c}{ Indikator } & Persentase \\
\hline $\begin{array}{l}\text { Kesesuaian } \\
\text { Penulisan dengan } \\
\text { Template }\end{array}$ & $84 \%$ \\
\hline $\begin{array}{l}\text { Komponen } \\
\text { Pendahuluan }\end{array}$ & $70 \%$ \\
\hline Komponen Metode & $84 \%$ \\
\hline $\begin{array}{l}\text { Komponen Hasil dan } \\
\text { Pembahasan }\end{array}$ & $78 \%$ \\
\hline $\begin{array}{l}\text { Komponen } \\
\text { Kesimpulan }\end{array}$ & $76 \%$ \\
\hline Komponen Referensi & $74 \%$ \\
\hline \multicolumn{1}{c}{ Rata-rata } & $\mathbf{7 8 \%}$
\end{tabular}

Berdasarkan Tabel 2, Penilaian tentang guru-guru matematika dalam membuat artikel ilmiah yang dipublikasikan secara online sudah baik. Diperoleh persentase sebesar rata-rata 78 $\%$ atau termasuk kategori baik. Pada sesi ini, guru pada awalnya mengalami kesulitan ketika membuat artikel ilmiah yang berstandar nasional setelah melihat 
dari contoh di open journal system (OJS). Namun, berjalannya waktu, para guru dapat menyusun dengan baik sesuai kaidah-kaidah yang berlaku dalam penulisan karya ilmiah (Setiawan \& Trisnawati, 2018).

Pada sesi terakhir, guru memberikan masukan dan pendapat mengenai penyelenggaraan pengabdian masyarakat ini. Respon positif sebesar $88 \%$ diberikan oleh para guru atas terselenggaranya kegiatan ini. Ada suatu harapan bahwa kegiatan ini akan berlanjut dengan pembahasan hal lain yang berkenaan dengan matematika. Berikut ini disajikan secara rincinya pada Tabel 3.

Tabel 3. Respon Guru terhadap Kegiatan Penyusunan Artikel Ilmiah dan Pengenalan Open Journal System (OJS)

\begin{tabular}{rc}
\hline Indikator & Persentase \\
\hline Kegiatan Sesi 1 & $88 \%$ \\
\hline Kegiatan Sesi 2 & $90 \%$ \\
\hline Kegiatan Sesi 3 & $86 \%$ \\
\hline Rata-rata & $\mathbf{8 8 \%}$ \\
\hline
\end{tabular}

\section{Kesimpulan dan Saran}

Berdasarkan hasil dan pembahasan sebelumnya, dapat disimpulkan bahwa guru mendapatkan wawasan dan pengetahuan tentang pentingnya publikasi ilmiah, $84 \%$ dari guru-guru matematika dapat mengaplikasikan open journal system (OJS) untuk publikasi ilmiah, $78 \%$ dari guru-guru matematika dapat membuat artikel ilmiah yang dipublikasikan secara online dan respon guru-guru terhadap kegiatan penyusunan artikel ilmiah dan pengenalan open journal system (OJS) sebesar $88 \%$ atau kategori baik.

Saran untuk kedepan, semoga kegiatan ini dapat berlangsung secara rutin dan dapat dilakukan pendampingan secara intensif antara guru dan dosen sehingga akan mendapat implikasi yang baik bagi gurunya dalam mempublikasikan artikel ilmiahnya.

\section{DAFTAR PUSTAKA}

Ceha, R., Prasetyaningsih, E., Bachtiar, I., \& Nana S., A. (2016). Peningkatan Kemampuan Guru dalam Pemanfaatan Teknologi Informasi pada Kegiatan Pembelajaran. ETHOS (Jurnal Penelitian Dan Pengabdian), 131. https://doi.org/10.29313/ethos.v0i0. 1693

Hamalik, O. (2011). Pengembangan Sumber Daya Manusia Manajemen Pelatihan Ketenagakerjaan Pendekatan Terpadu. In Proses Belajar Mengajar.

Inayah, S., Septian, A., \& Suwarman, R. F. (2020). Student Procedural Fluency in Numerical Method Subjects. Desimal: Jurnal Matematika, 3(1), 53-64. https://doi.org/10.24042/djm.v3i1.5 316

Maskur, R., Sumarno, Rahmawati, Y., Pradana, K., Syazali, M., Septian, A., \& Palupi, E. K. (2020). The effectiveness of problem based learning and aptitude treatment interaction in improving mathematical creative thinking skills on curriculum 2013. European Journal of Educational Research, 9(1), 375-383. https://doi.org/10.12973/eujer.9.1.375

N, A., Listihana, W. D., \& Nofrizal, N. (2018). Mendeley: Untuk Meningkatkan Kemampuan Menulis Dosen. ETHOS (Jurnal Penelitian Dan Pengabdian), 6(2), 274-281. https://doi.org/10.29313/ethos.v6i2. 3573

Praharani, N. S. (2007). Profesionalisme Guru Dalam Upaya Peningkatan Kualitas Pendidikan. Journal of Experimental Psychology: General, 136(1), 23-42.

Rathert, S., \& Okan, Z. (2015). Writing for publication as a tool in teacher development. ELT Journal, 69(4), 
14 Ari Septian, et al.

363-372.

https://doi.org/10.1093/elt/ccv029

Setiawan, M. A., \& Trisnawati, A. (2018). Pelatihan Publikasi Karya Ilmiah bagi Guru SMK Al-Inabah Kecamatan Babadan Kabupaten Ponorogo. Selaparang Jurnal Pengabdian Masyarakat Berkemajuan, 2(1), 18. https://doi.org/10.31764/jpmb.v2i1. 558

Willinsky, J. (2005). Open Journal Systems: An example of open source software for journal management and publishing. Library Hi Tech, 23(4), 504-519.

https://doi.org/10.1108/0737883051 0636300 